\title{
Analysis of the correlation between yield results and soil in the case of different genotype maize hybrids
}

\author{
Károly KITH - Csaba BOJTOR - Árpád ILLÉS - Zsuzsanna DOROGI - \\ Annabella ZELENÁK \\ Institute of Land Use, Technology and Regional Development, Faculty of Agricultural and Food Sciences \\ and Environmental Management, University of Debrecen, 4032 Debrecen, Böszörményi str. 138.; Email: \\ kithkaroly@agr.unideb.hu
}

Keywords: Zea mays, soil, Zink, hybrid, genotype

\section{Introduction}

Currently, cereal crops have the largest sowing areain Hungary. Cereals were grown on $56 \%$ of the utilized arable land. Of the above area, maize was sown 955,881 hectares in Hungary (HCSO). Our current challenges include the maintenance of maintaining the yield safety of maize, which is defined by genetic diversity. There is a steady improvement in terms of the yield safety of hybrids which is the result of the breeding of new hybrids. Hybrids involved in cultivation are genetically different,they show different reactions to the same agrotechnical and ecological factors. The aim of breeding is to maximize genetic yield potential. Considering the local characteristics of production areas, the most suitable hybrdis shall be selected (NAGY, 2006). The higher the FAO number of a maize hybrid, the longer is itsbreeding time and potential fertility. In Hungary, FAO-200-500 maize hybrids can be produced economically. The growth rate of maize is influenced not only by the biologicaland genetic background, but also by the location of production and its climatic conditions (NAGY, 2012). The length of the main sprout also depends on the hybrid and the conditions (BERZSENYI, 2012).

\section{Materials and methods}

The trial involved in present article is situated at the Látókép Experimental Site of the University of Debrecen.

The soil structure of the area is calciferous chernozem. The Arany plasticity index is around 43-47. Humus content of the upper $0-25 \mathrm{~cm}$ of the soil is $2.57 \%$. Water management characteristics of the soil are favourable, it is characterised by medium water fixation. Average depth of ground water is 3-5 m. It has a moderately acidic $\mathrm{pH}$ of 6.3-6.5.Climatic weather conditions are often characterised by continental and extreme factors.In terms of the growth period of 2018, there was a total of $317 \mathrm{~mm}$ precipitation, which is 22 $\mathrm{mm}$ less than the average value of 50 years. The trial was set up following the design of Prof.Dr.János NAGY, featuring early and medium maturity hybrids, which have a genetic profilein compliance with the current requirements.

Agro-technical characteristics of the trial:

The area of the trial is 0.29 ha. Its green crop is winter wheat; tillage methods: disc, subsoiling;nutriment supply $30 \mathrm{~kg} \mathrm{~N}, 78 \mathrm{~kg} \mathrm{P}, 78 \mathrm{~kg} \mathrm{~K}$. In spring: $135 \mathrm{~kg} \mathrm{~N}+35 \mathrm{~kg} \mathrm{CaO}+25 \mathrm{~kg}$ $\mathrm{MgO}$, then in June $54 \mathrm{~kg} \mathrm{~N}+14 \mathrm{~kg} \mathrm{CaO}+10 \mathrm{~kg}$ MgOfertilizer was applied. Between 23.07.2018 and 14.08.2018 $8 \mathrm{~mm}$ of irrigation water was applied every two days through the installed irrigation system. 


\section{Results and discussion}

Present study deals with the correlation of collected soil samples and the measured yield results. Six hybrids were selected from the trial. Following the collection of soil samples, the analysis of the samples was carried out in an accredited laboratory.

The results are the following:

Table 2: Soil samples results

\begin{tabular}{|c|c|c|c|c|c|c|}
\hline \multicolumn{7}{|c|}{ Soilsamples results $(\mathrm{mg} / \mathrm{kg})$} \\
\hline Hybrids & H1 & H2 & H3 & H4 & H5 & H6 \\
\hline Nitrogen & 10 & 24 & 9 & 16 & 11 & 5 \\
\hline Potassium & 150 & 171 & 186 & 201 & 198 & 164 \\
\hline Phosphorus & 84 & 131 & 183 & 172 & 168 & 94 \\
\hline Zinc & 0,6 & 0,6 & 0,7 & 0,7 & 0,7 & 0,6 \\
\hline
\end{tabular}

The analytical results of the study show the outstanding differences in terms of the different chemical elements. The low zinc content in the soil suggests that zinc was utilized by plants with high efficiency; they incorporated it into their system, which largely contributes to yield growth. There are large differences in terms of phosphorus, as in the soil sample of the H3 hybrid, the phosphorus content was $183 \mathrm{mg} / \mathrm{kg}$ and in the soil sample of H1 it was $84 \mathrm{mg} / \mathrm{kg}$. There was no similar fluctuation in terms of potassium. Interesting results can be seen with regard to nitrogen; with the second highest nitrogen content of $16 \mathrm{mg} / \mathrm{kg}$ in the case of the $\mathrm{H} 4$ hybrid with the highest yield, whereas the yield of the highest nitrogen content sample $(24 \mathrm{mg} / \mathrm{kg})$ is only the fifth amongst the analysed hybrids.

\section{Conclusions}

Cereals were grown on $56 \%$ of the utilized arable land Hybrids involved in cultivation are genetically different, they show different reactions to the same agrotechnical and ecological factors. The trial involved in present article is situated at the Látókép Experimental Site of the University of Debrecen. The trial was set up following the design of Prof. Dr. János NAGY, featuring early and medium maturity hybrids, which have a genetic profilein compliance with the current requirements. Present study deals with the correlation of collected soil samples and the measured yield results.

\section{Acknowledgement}

The research was financed by the Higher Education Institutional Excellence Programme of the Ministry of Human Capacities in Hungary, within the framework of the 4.thematic programme of the University of Debrecen, and the projects "GINOP-2.2.1-15-2016-00001

- Developing a scale-independent complex precision consultancy system" and "EFOP3.6.3-VEKOP-16-2017-00008".

\section{References}

Berzsenyi Z. (2012): Fenntarthatószemléletüszántóföldinövénytermesztéstan 2. pp.11-85. (Szerk. Radics L.) Budapest. 700.p.

http://www.ksh.hu/docs/hun/xftp/gyor/vet/vet1806.pdf

Nagy J. (2006): Maize production, Akadémiaikiadó. Budapest

Nagy J. (2012): Versenyképeskukoricatermesztés. MezőgazdaKiadó. Budapest. 494.p. 